\title{
EMERGING TECHNOLOGY: INTRODUCING TABLEAU TO CIS AND NON-CIS MAJORS IN A CORE BUSINESS CLASS
}

\author{
William A. Kapakos, Western Carolina University, wakapakos@email.wcu.edu \\ Barbara Jo White, Western Carolina University, whiteb@email.wcu.edu \\ Danial L. Clapper, Western Carolina University, clapper@email.wcu.edu \\ Lorrie Willey, Western Carolina University, Iwilley@email.wcu.edu
}

\begin{abstract}
Visual analytics and data science are increasingly important in industry for entry-level positions on up. While data analytics classes have been popular as stand-alone classes or as classes within an undergraduate major or minor, particularly majors or minors in computer information systems (CIS), visual analytics topics rarely make their way into required core business classes that include students from all disciplines, not just students majoring in information systems. The contribution of this paper to the practice of information systems education is that it is among the first to include emerging technologies like Tableau in a core business class for all business majors. Such an integration also assists a business school in meeting the accreditation standards established by the Association to Advance Collegiate Schools of Business (AACSB), specifically the need to integrate "technology agility". This research will explore how a visual analytics tool like Tableau can be included in an undergraduate core information systems course. Activity design, with in-class and out-of-class, is described, student reaction to the course is discussed, and suggestions for future inclusion in core business classes are offered.
\end{abstract}

Keywords: Tableau, Visualization, AACSB Standards, Emerging Technologies, BI, Analytics

\section{INTRODUCTION}

"The knowledge that Tableau provides will assist in answering many business questions in the future." Non-CIS Student in Core CIS Business Class Including Tableau "I like using the program more than Excel"

CIS Student in Core CIS Business Class Including Tableau

All organizations need people who can communicate with data visualizations to both technical and non-technical audiences. Perhaps this is one reason that data visualization is one of the top 25 hottest skills (Bhatia, 2019). To answer this need for graduates skillful with data presentation and visualization, colleges and universities have responded with analytics and business intelligence courses at both the undergraduate and graduate levels. While some advocate for analytics and business intelligence courses for graduate students in Master of Science programs and elective courses in the more general Master of Business Administration programs, model curriculum guidelines for undergraduate courses in analytics and business intelligence are recommended for information systems students only (Gupta, Goul \& Dinter, 2015). However, limiting data visualization courses to undergraduate CIS majors leaves out a wide swath of graduates who will work in a wide variety of industries with data visualization and data presentation needs.

The integration of new data visualization technologies, like Tableau, into the business curriculum is in line with the Standards for Business Accreditation developed by the AACSB International. Both the current 2013 Standards and the proposed 2020 Standards emphasize the need for business school graduates to be competent in the use of technologies applicable to their respective programs and to demonstrate agility in recognizing and utilization new and emerging technologies.

\section{LITERATURE REVIEW}

\section{Tableau}

In 2020, Tableau was in Gartner's Magic Quadrant as a leader in Analytics and Business Intelligence (Ajenstat, 2020) for the eighth consecutive year (see Figure 1 on the following page). 


\section{Issues in Information Systems}

Volume 21, Issue 3, pp. 31-40, 2020

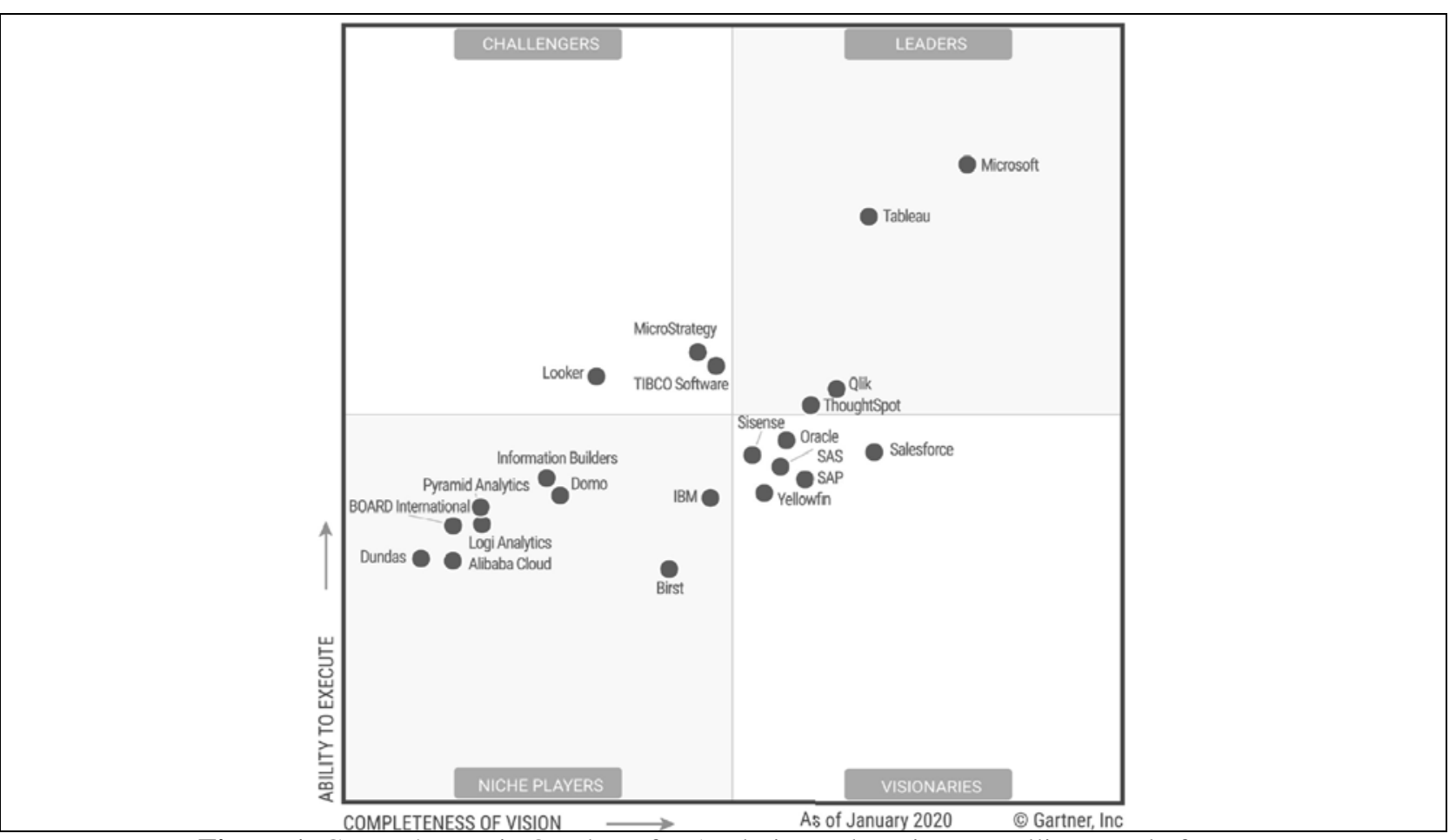

Figure 1. Gartner’s Magic Quadrant for Analytics and Business Intelligence Platforms

Tableau began with Stanford University research aimed at developing an interactive visual exploration tool that facilitated exploratory analysis of data warehouses with rich hierarchical structure (Polaris: interactive database visualization, n.d.). The research drew on three different areas: formal graphical specifications, table-based displays and database exploration tools (Stolte \& Hanrahan, 2002). The result was a tool that could create sophisticated visualizations using simple drag-and-drop operations to construct a visual specification (Stolte, Tang \& Hanrahan, 2008).

A more detailed description is "a declarative visual query language that unifies the strengths of visualization and database communities. It allows users to visualize relationships between data using shape, size, orientation, color and texture in all kinds of graphs, and leverages the advances in database systems to optimize performance of accesses to large datasets” (Gray, 2008, p. 74).

An important goal of the research was to support an iterative data exploration process allowing the user to test hypotheses, experiment visually and see the results as visual representations. The tool was also designed to quickly drilldown from a high level of abstraction to a much greater level of detail, even with large datasets (Stolte \& Hanrahan, 2002).

To accomplish this, the software was built on a visualization language which allowed intermediate states in the exploration process to be specified and so supported the construction of increasingly complex queries, while being able to display the results of each of the intermediate steps (Stolte et al., 2002). In a Communications of the ACM review, Gray (2008) suggested that it was a major improvement over how visual analysis was done at the time. This software was commercialized and extended and became Tableau Software (Stolte et al., 2008).

With a mission to "help people see and understand data", Tableau was founded in 2003 and had a public \$254 million offering in 2013 (“A mission that matters”, n.d., para. 1; Solomon, 2016; Ellet, 2019). It was acquired by Salesforce in 2019 for \$15.7 billion dollars (“Salesforce Signs Definitive Agreement to Acquire Tableau”, 2019). 


\section{AACSB Guidance on Emerging Technology}

The Association to Advance Collegiate Schools of Business International (AACSB) is actively involved with the process of integrating new technologies onto business schools' program curricula. Founded in 1916, the AACSB established a voluntary business school accreditation process that involves an examination of a business school capacity to comply with standards established by the organization. Through this mechanism, the AACSB works to improve business education globally. Its mission is "to foster engagement, accelerate innovation, and amplify impact in business education” (AACSB, “Who we are,” n.d., para. 4).

To meet this mission, the organization develops standards to which its members, and those institutions applying for AACSB accreditation, must comply. The Standards for Business Accreditation ("Standards") serve as specific guidance for all aspects of business education, including management, faculty qualifications, facilities, assurance of learning, and curricula develop (AACSB, "Standards Overview," n.d.). The standards are routinely updated to meet changing demands in business and the marketplace. The 2013 Standards are the most current, but 2020 Standards have been developed and are now in the proposal stage. A vote on these standards was originally set for Spring 2020, but the Covid-19 pandemic forced a postponement of the standards until 2021 (AACSB, "Blog,” 2016).

Specific wording in the current 2013 Standards applies to information systems and new technologies and uses the term "technology agility" (AACSB, 2013 Standards, n.d., p. 35). The focus is the inclusion of new and emerging technologies into curricula. Data analytics is specifically mentioned in this standard as is the use of technology as part of the decision-making process and the skills needed to be aware of and adapt new technologies (AACSB, 2013 Standards).

The proposed 2020 Standards recognize that "[t]he business environment is undergoing profound changes, spurred by powerful demographic shifts, global economic forces, and emerging technologies." (AACSB, 2020 Standards, p. 4). Now part of Standard 4: Curriculum, the emphasis on current and new technologies requires that "[t]he school has curricula that ...cultivates agility with current and emerging technologies (AACSB, 2020 Standards, n.d. p. 26). More particularly, is the requirement that emerging technology be "infused" in degree programs according to what is deemed appropriate for a specific degree program (AACSB, 2020 Standards, n.d. p. 27). As part of the evidence of this infusion, the AACSB Standard includes a table that, when completed, identifies the technologies, other than word processing and presentation software, "for which graduates would be able to demonstrate a moderate or better level of competency employed on each degree program” (AACSB, 2020 Standards, n.d. p. 28).

To meet the specific requirements of these standards, the incorporation of new technologies, such as Tableau, in an information systems survey course is a good fit. In such courses, students in a wide variety of majors and degree program can be exposed to new technologies that will be part of their workplaces. Employers are looking for those who have data analytics skills and those demands are across a wide variety of business professions, from accounting to supply chain management (Rodammer, Speir-Pero, \& Haan, 2015). To help improve student understanding and competency with emerging technologies, faculty can introduce assignments that require students to work with new software applications. Described as one of the simplest principles of learning, "the practice of a skill improves the performance of that skill” (Rohrer \& Stershic, 2015, p. 1). To practice and assess a skill related to an emerging technology, many teachers assign students practice problems like ones that appear on tests (Rohrer, et al., 2015).

\section{Model Curriculum Guidelines for CIS and Business Intelligence and Analytics}

The most recent version of the information systems curriculum guidelines (Topi, Valacich, Wright, Kaiser, Nunamaker, Sipior, \& de Vreede, 2010), which make mention information visualization and visual analytics, are nearly a decade old and need to be updated to effectively introduce the topics of business intelligence and data analytics to students (Gupta, Goul \& Dinter, 2015). However, the solution proposed by Gupta and colleagues (2015) is to create a model curriculum that includes Business Intelligence and Analytics as an elective in MBA programs, a core course in MS programs in business, and as a course for undergraduates who are information systems majors. Even though the use of emerging technologies, like Tableau, has been suggested in the new 2020 AACSB standards and suggested for undergraduate majors in CIS, there have been few published reports on the use Tableau in a required core information systems class for all types of business majors. This paper describes the inclusion of Tableau in a core business class required by all business majors. 


\section{TABLEAU ACTIVITIES IN A CORE BUSINESS INFORMATION SYSTEMS CLASS}

The current core class is standardized across all sections offered each semester (face-to-face and online) and contains three Excel labs with self-graded quizzes and three Access labs with self-graded quizzes. Prior to the first Excel lab quiz, a class period is spent introducing Excel and demonstrating rows and cells and simple formulas like sums and various ways to copy formulas. The second class involves going over a practice lab, which generally has 15 different steps to completion and has an image of the completed lab. The practice lab contains basic unit, cost and sales data with students completing formulas for gross sales, gross profit, totals and averages along with creating a pie chart. Following the second class, there is an out-of-class Excel lab and quiz with a 2.5-hour time limit wherein students complete a lab, which is similar to the practice lab with budget data, and formulas requiring totals, averages along with a pie chart. The lab also contains an image of the completed lab, which is always the first question in the quiz. Following completion of the lab, students are given multiple-choice questions asking them to interpret spreadsheet results directly or to change data in specific budget categories on the lab spreadsheet and interpret how the changes impact the budget over time. The second practice lab and quiz lab uses similar data as the first ones but looks forward and includes concepts of growth rates and forecasting and also contains an image of the finished lab. The third Excel quiz lab uses the same skills as the second lab and therefore omits both the practice lab and the image of the finished lab.

\section{Class 1: Introducing Tableau}

Much like the introduction for Excel, the first class period introduced Tableau and the Tableau interface (see Figure 2 below). As the instructor demonstrated Tableau, students were invited to follow along and click around to familiarize themselves with the interface. With students from a variety of business majors in the class, the use of Tableau in business across various disciplines was also discussed.

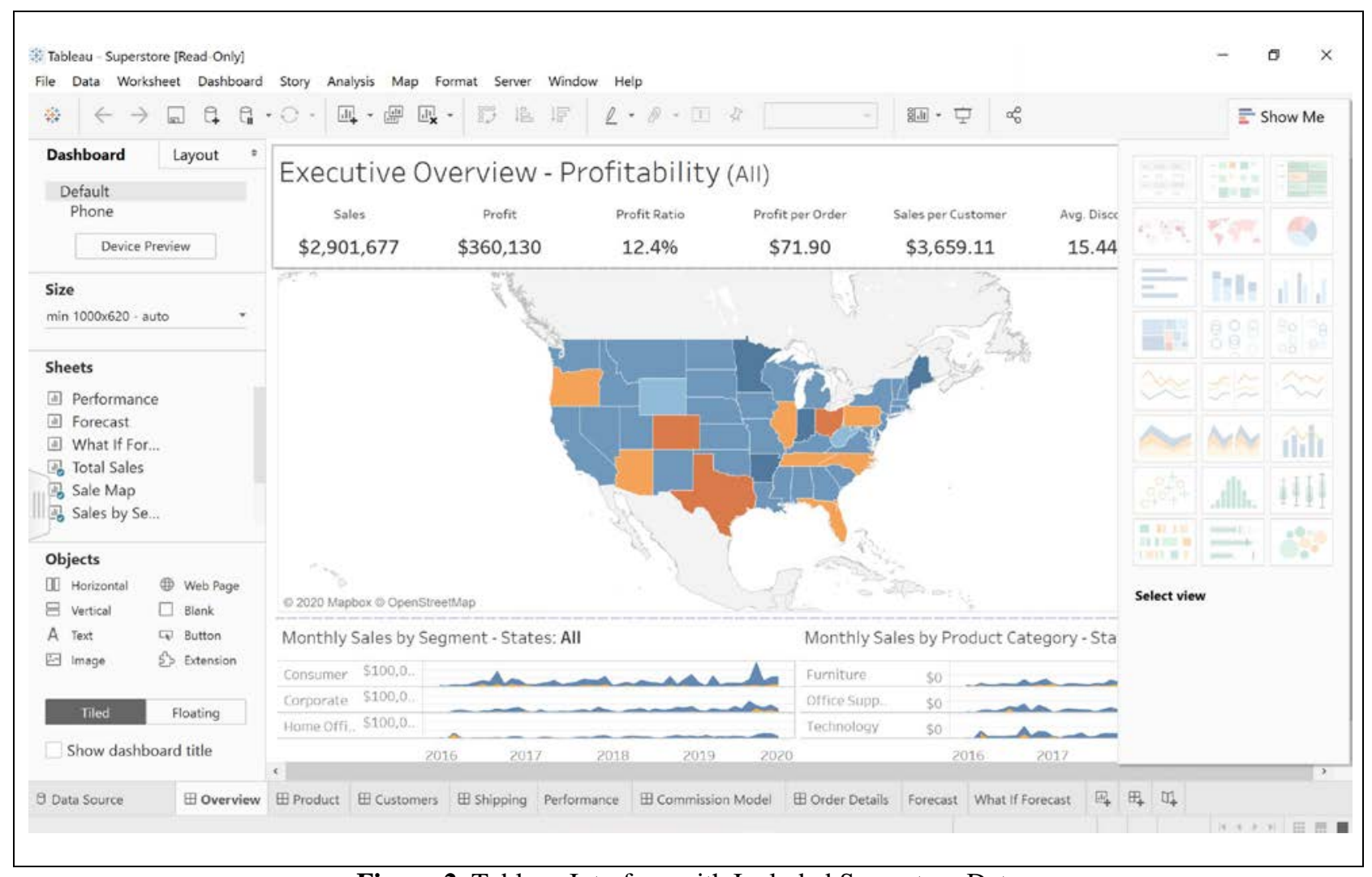

Figure 2. Tableau Interface with Included Superstore Data 


\section{Issues in Information Systems}

Volume 21, Issue 3, pp. 31-40, 2020

\section{Class 2: Tableau Practice Lab}

The second class for Tableau allowed the instructor and students the opportunity to complete a Tableau practice lab, with instructions that were in a similar format as possible to previous Excel practice labs that students were familiar with (see Figure 3 below).

This lab will use the default data source named, "Sample - Superstore"
Notes:
- The chart solution images are provided below
You must create the following charts in Tableau. Then, insert screenshots of each completed
include the time in the lower righth hand corner.
Create the following charts using the provided default data source in Tableau. Name the charts Chart
1, Chart 2, Chart 3, etc.
1. Create a line chart to show quarterly profits over time
If monthly profits over time were shown, what would the profit be for May 2016?
2. Create a bar chart to show profits by quarter
3. Create a line multi-line chart to show monthly profits by category
4. Create a line chart to show quarterly sales by category
5. Create a multi-line chart to show quarterly profits by segment for a selected date range
6. Create a multi-line chart to show monthly sales for selected regions and date range

Figure 3. Tableau Practice Lab Instructions

Students were also able to see screenshots of the finished project, just as they were in previous Excel labs. In addition, the Tableau practice lab chart images also included watermarks to make sure students did their own work (see Figure 4 below).

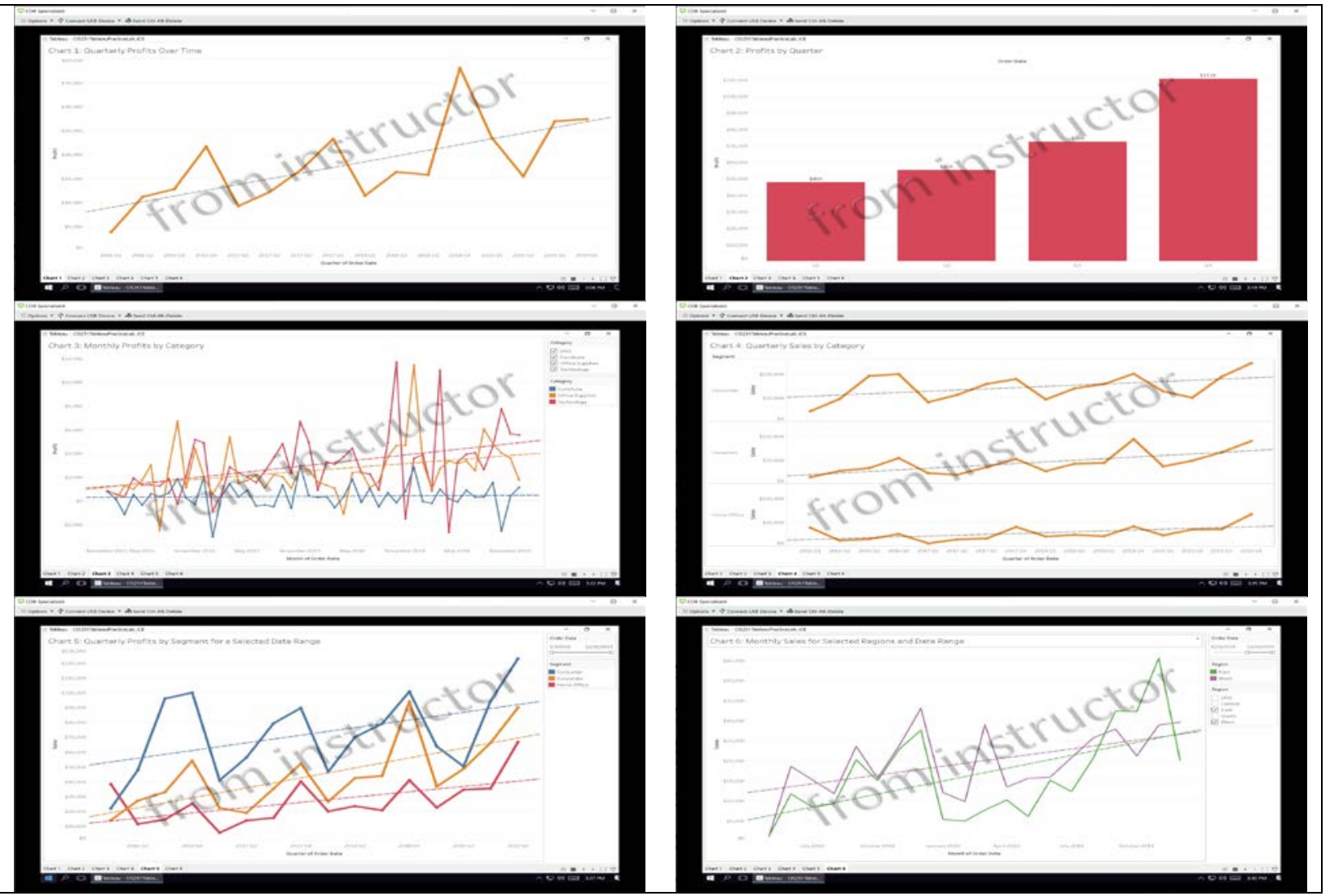

Figure 4. Images with Watemarks of Finished Tableau Practice Lab Available to Students 


\section{Issues in Information Systems}

Volume 21, Issue 3, pp. 31-40, 2020

\section{Out-Of-Class Activity: Tableau Lab and Quiz}

A Tableau lab was created that mirrored the skills demonstrated in the Tableau Lab 1 Practice Lab exercise from the second class. The instructions followed a similar format as with the practice lab exercise done in class (see Figure 5 below).

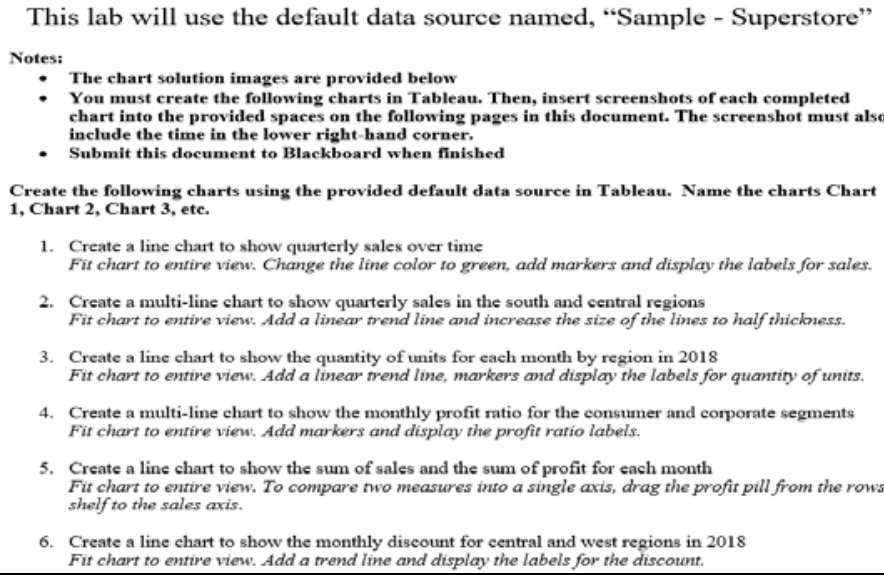

5. Create a line chart to show the sum of sales and the sum of profit for each month Fit chart to entive view. To compare two measures into a single axis, drag the profit pill from the row shelf to the sales axis.

6. Create a line chart to show the monthly discount for central and west regions in 2018 Fit chart to entive view. Add a trend line and display the labels for the discount.

Figure 5. Instructions for Tableau Lab Part of the Tableau Lab Quiz 1

Again, students were given images of the finished lab charts with watermarks (see Figure 6 below).
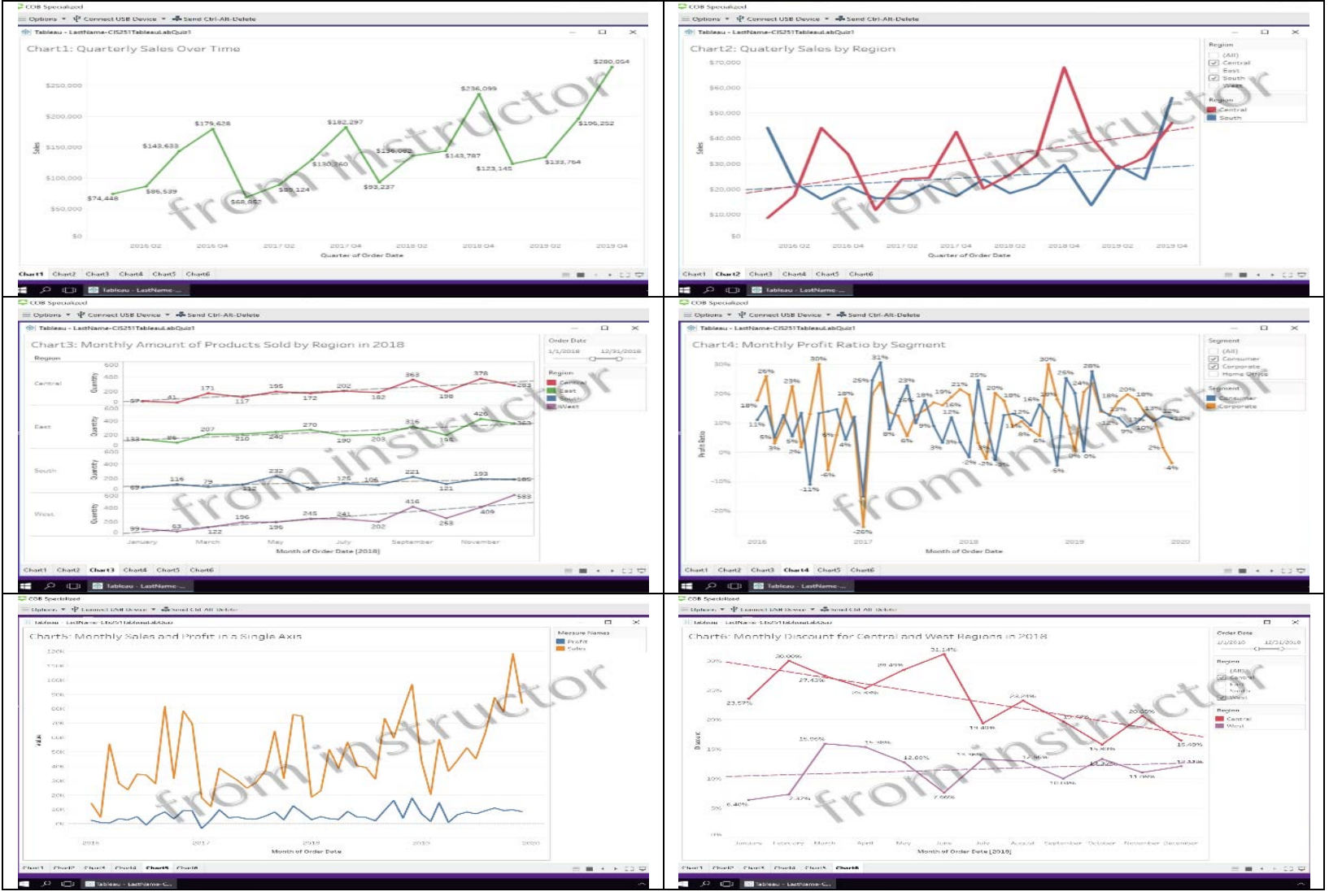

Figure 6. Images with Watermarks of Finished Tableau Lab Project With Tableau Lab Quiz 1 
The self-graded quiz questions after the lab followed a similar format as the Excel quizzes in that the Tableau quiz asked students to make interpretations directly or to change a column of data in the Tableau chart and then make interpretations in the form of answering multiple choice questions.

\section{STUDENT RESPONSE TO INSTRUCTION-METHODOLOGY}

A survey was used to measure student response to the Tableau activities. Survey items covered statements comparing Tableau to Excel, the importance and use of Tableau, as well as the Tableau lab activity (see Table 2 on the following page). The survey was administered as the last question on the Tableau lab quiz activity.

\section{RESULTS}

Twenty surveys, with twenty-one items each, were completed by the students in the core business information systems course. The sample (see Table 1 below) contained more males (55\%) than females (45\%) and many more non-CIS majors (85\%) than CIS majors (15\%). The non-CIS majors included undergraduate students majoring in management (15\%), accounting, (15\%), finance (10\%), marketing (10\%), sport management (15\%), hospitality and tourism (5\%), business law (5\%) and other disciplines (10\%).

Table 1. Demographics

\begin{tabular}{|c|l|c|}
\hline \multirow{2}{*}{ Gender } & \multicolumn{1}{|c|}{ Majors } & $\begin{array}{c}\text { \# of Survey } \\
\text { Responses }\end{array}$ \\
\hline \multirow{2}{*}{ Female } & CIS Majors & 2 \\
\cline { 2 - 3 } & Non-CIS Majors & 7 \\
\hline \multirow{2}{*}{ Male } & CIS Majors & 1 \\
\cline { 2 - 3 } & Non-CIS Majors & 10 \\
\hline
\end{tabular}

Students were asked to identify how much they agreed or disagreed with the statement and rated each item using a 5-point Likert scale with "1" = "Strongly Disagree” to "5” = "Strongly Agree.”

\section{Students and Tableau}

One-sample t-tests were conducted to determine student perceptions of Tableau. The means for items concerning Tableau and Excel, using Tableau, and the Tableau lab activity all differed from the neutral value in a more positive direction, with the exception of the items "I liked Tableau more than Excel" and "I feel more successful with Tableau than Excel." However, none of the differences were statistically significant. Regarding items concerning the importance of Tableau, all were statistically significant. Students in the course thought Tableau was beneficial to majors in their discipline $(M=3.70, S D=1.17), t(19)=2.67, p=.015)$ and that Tableau could help them find a job $(M=3.65, S D=1.23), t(19)=2.37, p=.028)$. In addition, students believed that Tableau would be useful in the workplace $(M=3.70, S D=1.22), t(19)=2.57, p=.019)$.

\section{CIS and Non-CIS Majors and Tableau}

There were differences between CIS and non-CIS student's perceptions about Tableau. For example, CIS students believed Tableau was useful in the workplace $(M=5.00, S D=0.00)$ more than non-CIS students $(M=3.47, S D=$ $1.80, t(18)=2.20, p=.041)$. In addition, CIS students liked Tableau more than Excel $(M=4.33, S D=0.58)$, compared to non-CIS students $(M=2.47, S D=1.46, t(18)=2.14, p=.047)$.

\section{Gender and Tableau}

With respect to gender, independent samples t-tests showed there were no statistically significant differences. Even so, it's notable that the means for each survey items covering statements pertaining to the importance of Tableau were all higher for female students than for male students. For example, females $(M=4.22, S D=1.09)$ thought Tableau was more useful in the workplace than males $(M=3.27, S D=1.19)$ and females believed knowing something about Tableau could help them find a job in their discipline area $(M=4.11, S D=0.93)$ more than males 
$(M=3.27, S D=1.35)$ and finally, females thought majors in their various business disciplines would benefit from knowing Tableau $(M=4.11, S D=0.78)$ more than males did $(M=3.36, S D=1.36)$.

Table 2. Frequency Responses for Tableau Survey Items

\begin{tabular}{|c|c|c|c|c|c|c|}
\hline Tableau and Excel Survey Items & $\begin{array}{c}1= \\
\text { Strongly } \\
\text { Disagree }\end{array}$ & $\begin{array}{c}2= \\
\text { Disagree }\end{array}$ & $\begin{array}{l}3= \\
\text { Neither }\end{array}$ & $\begin{array}{c}4= \\
\text { Agree }\end{array}$ & $\begin{array}{c}5= \\
\text { Strongly } \\
\text { Agree }\end{array}$ & \\
\hline $\begin{array}{l}\text { I feel more successful with Tableau than } \\
\text { Excel }\end{array}$ & $\begin{array}{c}5 \\
(25 \%)\end{array}$ & $\begin{array}{c}1 \\
(5 \%)\end{array}$ & $\begin{array}{c}6 \\
(30 \%)\end{array}$ & $\begin{array}{c}6 \\
(30 \%)\end{array}$ & $\begin{array}{c}2 \\
(10 \%)\end{array}$ & \\
\hline I liked Tableau more than Excel & $\begin{array}{c}6 \\
(30 \%)\end{array}$ & $\begin{array}{c}4 \\
(20 \%)\end{array}$ & $\begin{array}{c}2 \\
(10 \%)\end{array}$ & $\begin{array}{c}5 \\
(25 \%)\end{array}$ & $\begin{array}{c}3 \\
(15 \%)\end{array}$ & \\
\hline It takes longer to learn Tableau than Excel & $\begin{array}{c}0 \\
(0 \%) \\
\end{array}$ & $\begin{array}{c}8 \\
(40 \%) \\
\end{array}$ & $\begin{array}{c}2 \\
(10 \%) \\
\end{array}$ & $\begin{array}{c}4 \\
(20 \%) \\
\end{array}$ & $\begin{array}{c}6 \\
(30 \%) \\
\end{array}$ & \\
\hline \multicolumn{7}{|l|}{ Importance of Tableau Survey Items } \\
\hline Tableau is useful in the workplace & $\begin{array}{c}1 \\
(5 \%)\end{array}$ & $\begin{array}{c}3 \\
(15 \%)\end{array}$ & $\begin{array}{c}3 \\
(15 \%)\end{array}$ & $\begin{array}{c}7 \\
(35 \%)\end{array}$ & $\begin{array}{c}6 \\
(30 \%)\end{array}$ & \\
\hline $\begin{array}{l}\text { Knowing something about Tableau can } \\
\text { help me find a job in my discipline }\end{array}$ & $\begin{array}{c}1 \\
(5 \%)\end{array}$ & $\begin{array}{c}4 \\
(20 \%) \\
\end{array}$ & $\begin{array}{c}1 \\
(5 \%)\end{array}$ & $\begin{array}{c}9 \\
(45 \%)\end{array}$ & $\begin{array}{c}5 \\
(25 \%) \\
\end{array}$ & \\
\hline $\begin{array}{l}\text { Majors in my discipline would benefit from } \\
\text { knowing Tableau }\end{array}$ & $\begin{array}{c}1 \\
(5 \%) \\
\end{array}$ & $\begin{array}{c}2 \\
(10 \%) \\
\end{array}$ & $\begin{array}{c}5 \\
(25 \%) \\
\end{array}$ & $\begin{array}{c}6 \\
(30 \%) \\
\end{array}$ & $\begin{array}{c}6 \\
(30 \%) \\
\end{array}$ & \\
\hline \multicolumn{7}{|l|}{ The Use of Tableau Survey Items } \\
\hline Learning to use Tableau was easy for me & $\begin{array}{c}3 \\
(15 \%)\end{array}$ & $\begin{array}{c}4 \\
(20 \%)\end{array}$ & $\begin{array}{c}2 \\
(10 \%)\end{array}$ & $\begin{array}{c}8 \\
(40 \%)\end{array}$ & $\begin{array}{c}3 \\
(15 \%)\end{array}$ & \\
\hline I find it easy to use Tableau & $\begin{array}{c}3 \\
(15 \%)\end{array}$ & $\begin{array}{c}5 \\
(25 \%)\end{array}$ & $\begin{array}{c}2 \\
(10 \%)\end{array}$ & $\begin{array}{c}8 \\
(40 \%)\end{array}$ & $\begin{array}{c}2 \\
(10 \%)\end{array}$ & \\
\hline $\begin{array}{l}\text { My interaction with Tableau was clear and } \\
\text { understandable }\end{array}$ & $\begin{array}{c}3 \\
(15 \%)\end{array}$ & $\begin{array}{c}3 \\
(15 \%) \\
\end{array}$ & $\begin{array}{c}4 \\
(20 \%)\end{array}$ & $\begin{array}{c}7 \\
(35 \%)\end{array}$ & $\begin{array}{c}3 \\
(15 \%) \\
\end{array}$ & \\
\hline $\begin{array}{l}\text { It would be easy for me to become skillful } \\
\text { using Tableau }\end{array}$ & $\begin{array}{c}3 \\
(15 \%)\end{array}$ & $\begin{array}{c}3 \\
(15 \%)\end{array}$ & $\begin{array}{c}4 \\
(20 \%)\end{array}$ & $\begin{array}{c}7 \\
(35 \%)\end{array}$ & $\begin{array}{c}3 \\
(15 \%)\end{array}$ & \\
\hline \multicolumn{7}{|l|}{ Tableau Lab Activity Survey Items } \\
\hline $\begin{array}{l}\text { The amount of instruction in Tableau was } \\
\text { just right }\end{array}$ & $\begin{array}{c}2 \\
(10 \%) \\
\end{array}$ & $\begin{array}{c}5 \\
(25 \%)\end{array}$ & $\begin{array}{c}6 \\
(30 \%) \\
\end{array}$ & $\begin{array}{c}5 \\
(25 \%) \\
\end{array}$ & $\begin{array}{c}2 \\
(10 \%) \\
\end{array}$ & \\
\hline $\begin{array}{l}\text { The practice Tableau lab we did in class } \\
\text { was a lot like the Tableau lab on the quiz }\end{array}$ & $\begin{array}{c}2 \\
(10 \%)\end{array}$ & $\begin{array}{c}3 \\
(15 \%)\end{array}$ & $\begin{array}{c}3 \\
(15 \%)\end{array}$ & $\begin{array}{c}9 \\
(45 \%)\end{array}$ & $\begin{array}{c}3 \\
(15 \%)\end{array}$ & \\
\hline $\begin{array}{l}\text { Once I finished the lab, the quiz questions } \\
\text { that asked me to change specific parts of } \\
\text { the chart in Tableau were easy for me to } \\
\text { answer }\end{array}$ & $\begin{array}{c}3 \\
(15 \%)\end{array}$ & $\begin{array}{c}3 \\
(15 \%)\end{array}$ & $\begin{array}{c}3 \\
(15 \%)\end{array}$ & $\begin{array}{c}7 \\
(35 \%)\end{array}$ & $\begin{array}{c}4 \\
(20 \%)\end{array}$ & \\
\hline $\begin{array}{l}\text { I got a good grade on the Tableau lab with } \\
\text { quiz }\end{array}$ & $\begin{array}{c}4 \\
(20 \%)\end{array}$ & $\begin{array}{c}2 \\
(10 \%)\end{array}$ & $\begin{array}{c}4 \\
(20 \%)\end{array}$ & $\begin{array}{c}7 \\
(35 \%)\end{array}$ & $\begin{array}{c}3 \\
(15 \%)\end{array}$ & 口_ \\
\hline $\begin{array}{l}\text { I am good at understanding Tableau charts } \\
\text { and what they mean }\end{array}$ & $\begin{array}{c}4 \\
(20 \%) \\
\end{array}$ & $\begin{array}{c}1 \\
(5 \%)\end{array}$ & $\begin{array}{c}4 \\
(20 \%)\end{array}$ & $\begin{array}{c}8 \\
(40 \%) \\
\end{array}$ & $\begin{array}{c}3 \\
(15 \%)\end{array}$ & 口_ \\
\hline
\end{tabular}

\section{CONCLUSIONS AND TABLEAU ACTIVITIES IN FUTURE CIS CORE CLASSES}

It was good to see that students with various majors in the CIS core course recognized the benefit of knowing Tableau to their various disciplines, the benefit of Tableau in their job searches, and Tableau's usefulness in their future workplaces. It was also good to see that students did not perceive using Tableau to be any easier or any more difficult than using Excel, particularly because at the end of the course, they were exposed to Excel more than Tableau. 


\section{Issues in Information Systems}

Volume 21, Issue 3, pp. 31-40, 2020

Due to the pandemic, students were not able to be reminded and encouraged to complete the Tableau assignment in a face-to-face setting which likely contributed to the small sample size. The sample size also contained a larger number of non-CIS students compared to CIS students because all business students take the core course.

The Tableau exercises will be fully integrated in core information systems courses in future semesters. To do that, a second Tableau practice lab and lab quiz will be created. This lab will use the same data set as the first practice lab and quiz; however, additional variables will be included and additional charts and dashboards so as to add a level of difficulty that is consistent with the three Excel and three Access labs and quizzes used currently in the course. To make room for the inclusion of the two Tableau labs and quizzes, the third Access lab and quiz will be removed from the course. Instructional Tableau videos will be created, and future research conducted to identify how teaching Tableau in the face-to-face environment differs from teaching Tableau in the online environment.

\section{REFERENCES}

AACSB International (n.d.) 2013 Standards for Business Accreditation. Retrieved from https://www.aacsb.edu//media/aacsb/docs/accreditation/business/standards-and-tables/2018-businessstandards.ashx?la=en\&hash=B9AF18F3FA0DF19B352B605CBCE17959E32445D9

AACSB International (n.d.). 2020 Standards for Business Accreditation. Available: https://www.aacsb.edu//media/aacsb/docs/accreditation/business/standards-andtables/proposed\%202020\%20aacsb\%20business\%20accreditation\%20standards\%20\%20final\%20draft\%20\%20april\%206\%202020.ashx?la=en\&hash=B40646D6F0057FBAF289B3B04888A33BB2741A3D

AACSB International (n.d.). Standards overview. Available: https://www.aacsb.edu/accreditation/standards/business

AACSB International (n.d.). Who we are. Available: https://www.aacsb.edu/about/who-we-are

Ajenstat, F. (2020). Tableau a leader in the 2020 Gartner Magic Quadrant. Available: https://www.tableau.com/about/blog/2020/2/tableau-leader-2020-gartner-magic-quadrant

Bhatia, R. (July 2, 2019). Why learning data visualization should be on every data science aspirant's radar. Available: https://analyticsindiamag.com/why-learning-data-visualization-should-be-on-every-datascience-aspirants-radar/

Blog, (March 16, 2020). From AACSB International. Available: https://www.aacsb.edu/blog/2020/february/exposure-draft-2-of-2020-standards-finishing-strong

Diamond, M., \& Mattia, A. (2017). Data visualization: An exploratory study into the software tools used by businesses. Journal of Instructional Pedagogies, 18, 1-7.

Ellet, E. (2019). Tableau: The wiz of data vis prepares for new era. Forbes. Available: https://www.forbes.com/sites/moorinsights/2019/11/25/tableau-the-wiz-of-data-viz--prepares-for-new-era/

Gray, J. (2008). Technical perspective: The Polaris tableau system. Communications of the ACM, 51(11), 74-74

Gupta, B., Goul, M., \& Dinter, B. (2015). Business intelligence and big data in higher education: Status of a multiyear model curriculum development effort for business school undergraduates, MS graduates, and MBAs. Communications of the Association for Information Systems, 36(1), 449-476.

Mitchell, R. B., \& Thambusamy, R. (2017). Integration of business analytics knowledge and skill development into the undergraduate business core. Journal of Research in Business Information Systems, 10(10), 1-32.

Polaris: interactive database visualization (n.d.). Available: http://graphics.stanford.edu/projects/polaris/ 
Rodammer, F., Speier-Pero, C., \& Haan, J. (2015). The integration of business analytics into a business college undergraduate curriculum. 2015 Twenty-first Americas Conference on Information Systems. Available: https://aisel.aisnet.org/cgi/viewcontent.cgi?referer=https://www.google.com/\&httpsredir=1\&article=1288\& context=amcis2015

Rohrer, D., Dedrick, R. F., \& Stershic, S. (2015). Interleaved practice improves mathematics learning. Journal of Educational Psychology, 107(3), 900-908.

Salesforce signs definitive agreement to acquire Tableau. (2019, June 10). Available: https://investor.salesforce.com/press-releases/press-release-details/2019/Salesforce-Signs-DefinitiveAgreement-to-Acquire-Tableau/default.aspx

Solomon, B. (2016). How Tableau built a $\$ 3$ billion data empire on top of beautiful charts. Forbes. Available: https://www.forbes.com/sites/briansolomon/2016/05/04/how-tableau-built-a-3-billion-data-empire-on-topof-beautiful-charts/

Soule, L., Fanguy, R., Kleen, B., Giguette, R., \& Rodrigue, S. (2017). Towards meeting the need for data analytics skills in business students. 2017 Refereed Proceedings of the Association of Business Information Systems, $1-9$.

Soule, L., Fanguy, R., Kleen, B., Giguette, R., \& Rodrigue, M. S. (2018). Evolution of a first course in data analytics for business students. Journal of Research in Business Information Systems, 10(10), 55-73.

Stolte, C., Tang, D., \& Hanrahan, P. (2002). Polaris: A system for query, analysis, and visualization of multidimensional relational databases. IEEE Transactions on Visualization and Computer Graphics, 8(1), 52-65.

Stolte, C., Tang, D., \& Hanrahan, P. (2002, July). Query, analysis, and visualization of hierarchically structured data using Polaris. In Proceedings of the eighth ACM SIGKDD international conference on Knowledge discovery and data mining, 112-122.

Stolte, C., Tang, D., \& Hanrahan, P. (2008). Polaris: a system for query, analysis, and visualization of multidimensional databases. Communications of the ACM, 51(11), 75-84.

Tableau (2020). A mission that matters. Available: https://www.tableau.com/about/mission

Topi, H., Valacich, J. S., Wright, R. T., Kaiser, K., Nunamaker, Jr., J. F., Sipior, J. C., \& de Vreede, G. J. (2009). IS 2010: Curriculum Guidelines for Undergraduate Degree Programs in Information Systems.

Communications of the Association for Information Systems, 26, 359-428. 